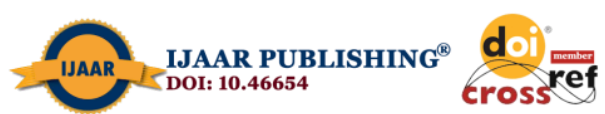

International Journal of Advanced Academic Research | Social and Management Sciences | ISSN: 2488-9849

Vol. 6, Issue 5 (May, 2020) | www.ijaar.org

Journal DOI: www.doi.org/10.46654/ij.24889849

Article DOI: www.doi.org/10.46654/ij.24889849.s6552

\title{
NIGERIA DEPOSIT INSURANCE CORPORATION AND BANKS PERFORMANCE: TREND ANALYSIS
}

\author{
${ }^{1}$ Nwanyanwu, H. Dennis, Ph. D and ${ }^{2}$ Okowa I. Okowa \\ Kenule Beeson Saro-Wiwia Polytechnic, Bori, Port Harcourt \\ Tel: +2348033404189 \\ E-mail: nwanydennism@gmail.com
}

\begin{abstract}
Ensuring stability in the banking sector was a priority to guarantee depositors confidence in the sector. This paper did a trend analysis of Banks performances under the supervisions of NDIC from 1990 to 2018. Secondary data were sourced from CBN, NDIC annual Statistical Bulletin from 1990 to 2018. The estimated model parameters were analyzed using the Ordinary Least Square regression (OLS) method and tested hypotheses. The descriptive analysis explained the trend of banks performances based on selected variables; "Return on Assets, Number of Insured Depositors, Total Bank Insured Premium, Total bank Deposits and Liquidation Dividend". The trend analysis revealed that Returns on Assets increased within 1990 to 2007 period which represented an all-time high in the banking sector but picked up in 2011 due to the banks consolidation exercise. It was also explained that the number of insured deposits has been on a steady rise up to 2018 which is attributed to the creation of deposit insurance scheme. There was a steady drop in liquidation dividend due to drop in banks failures while banks insured premium increased. The paper suggested for NDIC to embark on strict supervision, within their authority, to prevail on every bank to transmit their premiums as and when due. In pursuit of corporate governance, NDIC should ensure that every loan taken from the banks are traced to the real borrower to avoid insider loan which has been the cause of major bank failures.
\end{abstract}

Keywords: Deposit Insurance, Corporation, Assets, Trend, Analysis 


\section{Introduction}

Performance of every business is a function of profit level which is measured based on return on assets (ROA). The greater the ROA, the more a firm's progress in terms of profit or performance. Return on assets entails the ratio of profitability which explains a firms profit generated and gives a picture of a firm's performance. This performance is usually determined by certain factors as measurement yardstick. It also reflects how well the supervision and monitoring activities of Central Bank of Nigeria and Nigeria Deposit Insurance Corporation (NDIC) has positively affected banks performance. Considering the deposit insurance scheme of NDIC, the activities if financial institutions are streamlined to encourage consistent reliance of bank customers on the ability of banks to delivers expected services. It assures depositors the safety of their funds in the hands of financial operators. Bank's capital adequacy, the ability to meet respond to customers' daily cash demand and the level of declared profits at the end of every fiscal year is a reflection good performance (Apere, 2016). Nzotta (2004) cited in Apere (2016), posited that banks derive their strong financial base on the available capital since banks value is also a function of net future earnings which assures the customers the safety of their money. As believed by several scholars; (Hassan Bashir, 2003: Apere, 2016), besides supervisory role of the NDIC, a bank's strength and profitability is measured by its investment level and availability of credits facilities to the public. The explanation is that as customers deposit their money with the banks, banks in turn, insure the received deposits by depositing a certain sum with the NDIC for reasons of support, efficacy, and stability, at the same time encourage a reliable and effective payment system.

Invariably, banking practice plagued by possible occurrence of unsafe, doggy and unsound activities are constantly checked. Basically, NDIC undertakes risk-based, consolidation and transactions based supervisions in her duties to banks. Imperative, it is the pursuance of corporate government as key to ensuring ultimate performance of banks. This key factor lies on the shoulders NDIC which in addition to overseeing the activities of both banks, adopts stringent measures enshrined in the Act that established it. While deposit insurance scheme (DIS) oversees the payment of insured deposit premium of from banks to insure the deposits collected by unsophisticated depositors to instill confidence and stability in the banking system, enforcement of corporate governance ensures the control the activities of banks' management (Chief Executive Officers) and directors. They are all supervised by NDIC. To this end, the introduction of corporate governance was part of the reforms introduced by CBN to sustain the ability of banks to effectively remain in business. Corporate governance was an attempt to modify ownership structure/control rights of individuals or co-owners of a bank. Under corporate governance, risk management department was created and no one individual is becomes both the chairman and managing director at the same time. The reform further stated that no person should be managing director for more than ten years (Onuoha, 2015). The underlying reason for corporate governance is to re-organize ownership structure of banks, allow the board oversee managing directors' activities and identify early, problems that may result to distress and eventual failure.

\section{Statement of Problem}

Banks crisis that resulted to the creation of NDIC caused enormous setbacks in the economy. Tracing the phases of crisis in Nigeria banking sector, Iwedi (2017) cited in Ogboru (2019), enumerating the four phases of financial crisis in Nigeria established that financial crisis deepening occurred between "1936 - 1968, 1968 - 2000, 2000 - 2004 and 2004 - 2011)". 
Within these periods, banks went into severer distresses and eventually failed. Investors and their investments were faced with high tough and unfriendly business environment as cost of imports soared, exchange rate rose astronomically with increasing high food prices. Funds were withdrawn from one investment to another. However, the banking reform and federal government consolidation of banks of 2004/2005 and eventual creation of NDIC was considered a relief to bank customers. Following the above, the question is whether banks performances and investments increased as a result of the recapitalization. To this end, our study objective is to conduct performance trend analysis within the reviewed period using considered measurement variables.

Specifically, the paper undertakes descriptive analysis of year-by-year trend of banks performance based on NDIC supervisions from 1990 to 2018 measured by "Return on Assets" (ROA) with other variables; Number of Insured Depositors, Liquidation Dividend, Total Bank Deposits and Total Bank Insured Premium. It therefore became imperative to adopt trend analysis to review this topic and create a robust perspective about NDIC activities and performance of banks in Nigeria.

This paper is limited to the analysis of NDIC activities and performance of banks in Nigeria from 1990 to 2018. It addresses activities of NDIC within the framework of banks return on assets as dependent variable and number of insured depositors, total bank insured premium, total bank deposits and liquidation dividend. The paper began with introduction. Problem statement and the objectives were stated.

Scope and significance were also discussed. These were followed by the literature and descriptive explanations of the analyses based on presented data. Discussed were the findings and the paper concluded with suggested remedies and further studies.

\section{REVIEWED LITERATURE}

\section{Conceptual Issues}

Bank is an establishment authorized by law for deposit acceptance, clear checks, issue loans, pay interest, provide loans to customers and other functions. Banks may also provide financial services, such as wealth management, currency exchange, and safe deposit boxes (Igweike, 2005). A bank may be commercial/retail, development, industrial or investment bank. Her incomes could generated through interest charges or profits from investments. It effectively acts as an intermediary between savers (depositors) and investors who may need the money. Accepting short-term deposits and issuing long-term loans by bank creates a mismatch (Yusuf, 2015). The underlying motive is profit which can be measured as a return on assets or equity. Invariably, it is the difference between the profit amounts obtained from the assets and expense of the liabilities. Given these definitions by scholars, bank is not only a place to secure funds and other valuables, but a collective place of vault for financial security, statutorily created by law because it involves the agreement of both the banker and the customer.

The capital base of a firm is the minimum share capital required of a firm or corporate entity to have and maintain during the time in which the business remains a going concern. It entails a base level of funding. For individual investors, capital base refers to money used to purchase an initial investment and subsequent purchases of that investment (Kuye, Ogundele \& 
Otike-Obaro, 2013). The term "Capital Base" refers to the generated fund by a firm from public offering. It is usually the reserved fund or capital that must not be tempered with for the sake of unsecured and secured creditor's interest. The fact is that shareholders interest depends on it (Wise Geek, 2015). Thus, firms with hug capital base attracts more investors or public and private partnership hence growth of that sector and the economy in the long run. During the 2005 recapitalization of banks, every commercial bank, operating within every state of the federation, was required to maintain a minimum capital base of Twenty-Five Billion Naira (25b) and a capital adequacy ratio of 10\% (Iyede, Onah \& Osusu, 2018).

Bank performance explains how well the bank has done when assessed based on preceding year's achievements. Level of shareholders dividend clearly attests whether a bank is performing well or not. Performance determinants could be internal or external. Internal determinants consider factors not limited to size, capitalization measured by ratio of equity to assets ratio, liquidity, credit quality, efficiency measured by the ratio of overheads to total assets. Other parameters include control, degree of diversification, and amount of bank deposits, governance and market share.

However, organizations' performance encompasses three key areas; Financial Performance (return on assets or equity, monetary profits and return on investment and others),"Product Market Performance" - (market shares, sales etc.) and Shareholders return; - (total shareholders return, economic added value etc.).

\section{Brief History of Nigeria Deposit Insurance Corporation}

The emergence of Deposit Insurance Corporation (DIC) is traceable to United States of America (USA) before the civil war. The corporation was established to maintain currency value. In 1924, the corporation was established in former Czechoslovakia (presently Czech and Slovak Republic). In 1933, the USA formally established her Federal Deposit Insurance Corporation. In a space of twenty four years, the idea has been sold to several countries of the world. In Asian; India 1961, Philippines 1963 and Sri Lanka 1987. In Europe; Germany 1976, Britain 1979, and France 1980respectively. In Africa; Kenya 1985, and Nigeria 1988 as aftermath of the 1986 Structural Adjustment Program (SAP) which had the backings of Decree No. 22 of 1988. Ganiyi (2014) in his outline, added that the NDIC also performs specific functions not limited to the following functions; (i) Deposit Insurance, (ii) Bank Supervision, (iii) Bank Customers' Enlightenment, (iv) Distress Resolution, (v) Bank Liquidation, (vi) Insure that deposit liabilities of licensed banks, (vii) Guarantee payments to depositors in the financial or banking sector, (viii) Assist monetary authorities to formulate and implement policies, (ix) Adopt bank liquidation measures for banks that fail to respond to failure resolution, (x) Ensure resolution of failed institutions, (xi) Render assistance to insured institution in the interest of depositors and (xii) to pursue other measures necessary to achieve the functions of the corporation.

\section{Deposit Insurance Scheme}

Deposit Insurance scheme (DIS) was created by DIS Act 2006 under the supervision of NDIC. Ogunleye (2003) emphasized on specific functions of DIS as an agency under the NDIC supervision to include; (i) to provide deposit protection to financially unsophisticated depositors, (ii) ensure financial stability by promoting confidence and banking system stability, 
(ii) contribute to an orderly payments system, (iv) redistributing the cost of failures. Other functions are; to promote financial sector competition by reducing deposit-taking industry barriers, (v) assist monetary authorities to formulate and implement policies, encouraging economic growth and (vi) give assistance to insured institutions and facilitating the transition from full guarantee to limited coverage.

\section{THEORETICAL REVIEW}

\section{Stewardship Theory}

This paper has its underpinning from the "Stewardship Theory", conceptualized by Schoorman, Wilson, Davis, Hundley, \& Bagnoli (2012) as the act of delegation of responsibilities to individuals as service to towards utmost firms' performance. Set goals of making profits through better performance in a firm is pursued by the managers who at as stewards to the depositors or stakeholders. Better performance of the bank or firm is credited to the management and staff. In Steward Theory, there is both involvement and control oriented practices with optimum collaboration and trust (Jorge \& Serna-Gómez, 2012).

The management of a bank is entrusted with assignments on behalf of shareholders. This connotes stewardship. It is the responsibility of the Chief Executive officer to try and ensure the effective management of activities of a firm for maximum performance/profit. Here, banks customers are stakeholders who have entrusted their deposits in the hands of banks managements for optimum return. It is the responsibility of both managers and other staff of banks whose duties it is to operate on the guidelines and regulatory supervisions of both CBN and NDIC for maximum performance or return on assets. The performance guideline is better explained on adherence to corporate governance found within the framework of NDIC. When the financial resources of depositors are properly managed, there is increase in return on assets. In this regard, the question of insider loan, overstay of persons/staff as chief executive, being chief executive and at the same time director in the same bank is one of the major issues that border on corporate governance.

\section{REVIEW OF EMPIRICAL STUDIES}

The case of banks performance has been investigated by several scholars; (Oriaregbete, 2016: Uduak \& Ubom, 2017: Iwedi, 2018). Opening more discussions into the topic, Udo, (2015), in an attempt to determine the post rescue operational Stability of the seven Nigerian Banks rescued from an outright liquidation, adopted Altman's model in the study of the effectiveness of Nigerian Deposit Insurance Company Operations (NDIC) in Stabilizing the Nigerian Banking Sector, the study found that recently rescued Nigerian banks are still not sound and stable in their operations. Nigeria Deposit Insurance Corporation's supervisory efforts do not have any significant impact on the rescued banks provisions and arrangements for risks and obligation of paying depositors of affected banks does not have any significant impact on the stability of the Nigerian banking system. The paper suggested that NDIC should be unrelenting in their supervisory function of the banking system.

In another study, Oriaregbete (2016) assessed CBN regulations and banking operations in Nigeria. The intention was to show the essence of $\mathrm{CBN}$ guidelines which guarantees soundness, effectiveness and safety of the banking system. Adopting regression analysis, the 
study revealed the influence of $\mathrm{CBN}$ policies on banking activities. It was also discovered that there are varying reports on the inefficiency of some banks such as their internet services, ATMs showing temporarily unable to dispense cash syndrome, out-of-service syndrome, and excessive deduction of charges from customer deposits amongst other unethical practices. The paper suggested for the need for the banking supervision department to be more effective in its responsibilities in ensuring that banks activities are well supervised to reduce cases of mismanagement and non-performing loans. Banking regulation should not be to the detriment of small and medium scale business development. There should be moderation and direction in CBN monetary policies as it concerns banks loans to SMEs while also ensuring that the books of the banks remain healthy and not engage in unnecessary risky investment. Central Bank of Nigeria must also be sincere in its functions. And finally, that the government should ameliorated banks cost of doing business.

The work of Amire and Amire, (2016) further opened more discussions on NDIC and performance of banks in Nigeria. Studying "the effect of corporate external restructuring on the performance of financial modeling". Utilizing exploratory review method in the analysis, it was discovered that the crisis ravaging the sector over these periods have not been dealt with by the regulatory authority and other stakeholders in the sector, as such one could conclude that poor implementation of the prudential guidelines to a large extent, accounts for to the series of bank failure witness in Nigeria over the years. The work recommended strict regulations on banking sector activities in Nigeria. There is the need for strong coordination among regulatory authorities such that will encourage exchange of banks examination reports among themselves with the view to improve their supervisory and regulatory functions.

A study by Iyade (2006) conducted a study on "the impact of regulation and supervision of the activities of banks in Nigeria, 2000 - 2005. The study utilized descriptive statistics of percentages, mean score and Chi-square test in order to make comparison, test the hypotheses and draw conclusions. The work revealed non-significant relationship between bank practices and activities of CBN and NDIC. Increased activities of both agencies were suggested. It also suggested for increased awareness of banking activities within the general populace through a deliberate integration process was suggested. Abdulazeez, Ndibe and Mercy (2016) worked on corporate governance enforcement in Nigerian banks using multi-colinearity test of Pearson correlation and OLS and found that increased performance of banks was as a result of board size. Increased board size within approved limit was suggested.

Fitting an ANOVA model into "Stepwise Regression were implored by Gidigbi (2017) to study the effect of reforms in the economy and performance of banks Findings showed that banking reforms contribute positively to economic growth from 1999 to 2004 and negatively contributed negatively to banks' performances thereby show dual impact on the economy. The overall impact is that banking reforms can promote economic growth. The work suggested for implementation reforms before crystalizing its adverse effects. In furtherance, Uduak \& Ubom (2017) studied "a review of banking crisis and financial instability in Nigeria with a view to analyzing the trend, types, causes and resolution strategies employed in the country. Descriptive method was adopted in the analysis. The work considered the effect of micro and macro factors in the banking crisis and discovered managerial and macroeconomic policy efficiencies as root cause of banking sector crisis. The paper suggested for the application of integrated, preventive and administrative as well as continuous voluntary consolidation 
strategies to ensure stability in the banking system.

Evident prudential laxity of regulatory bodies against banks' failures in Nigeria was studied by Iwedi (2018) to critically examine bank failure in Nigeria and those responsible for such series of failures. It was found that the regulatory agencies failed in their enforcement activities on banks. A wake-up call in terms of enforcement/supervision was suggested while absolute adherence to prudential guideline by banks were recommended. The paper further suggested that there should be strong collaboration among the regulatory authorities such that will encourage exchange of banks examination reports. Mohammed, (2018) worked on "evidence determination of bank eradication in Nigeria using Pearson product coefficient of correlation to look at critical effective resolution mechanism. The paper discovered that NDIC has enhanced greater public among banks customers. The work suggested for strict adherence of code of corporate governance by all banks in Nigeria.

An analogy of crisis in Nigeria banks was studied by Iyede, et al. (2018) which gave an insight of past events in the banking sector between 1989 and 2014 using exploratory review of data from various publication. It was discovered that the period reviewed was crisis period for banks in Nigeria and the challenges in banks have remained unabated. It was suggested that mindful of ensuring non-repetition of the past experiences by banks would facilitate robust measure of banking crisis, thus adequate policy lessons from banking crisis occurrence.

Osadume and Ibenta (2018) evaluated stock market quoted deposit money banks performance in Nigeria from 2001 to 2014using OLS and unit root test. Relationship between capital adequacy, liquidity and banks performances were discovered. The paper recommended among others that Net Profit should not be the only basis for Deposit Money Banks performance evaluation; and Bank Managers as well as Regulatory Authorities should adopt globally accepted standards for evaluating bank's capital Adequacy, Assets Quality and Liquidity levels periodically.

\section{METHODOLOGY}

Research design for this paper is the mono-method quantitative research design using the ex-post facto strategy which was descriptively discussed to understand the trend of banks performance with the reviewed period. All the financial institutions that passed the CBN consolidation formed our study population. Sourced secondary data were got from CBN, NDIC Statistical Bulletin, National Bureau of Statistics (NBS) Annual reports covering 1990 to 2018.

\section{Operational Measures of Variables}

Independent Variables: Our aim is analyze the determining factors of return on assets hence bank profitability/good performance in Nigeria. Four factors/variables are selected for this study. Among these are factors are; total number of deposits insured, total amount insured, total bank issued premium and percentage of liquidation dividends.

\section{(i) Total Number of Depositors Insured:}

An Insured deposit is a comprehensive description of DIS insurance coverage for the most account ownership categories. It usually comprised common account coverage; savings, current and fixed deposit accounts, including interest. Outstanding or uncleared balances for 
which institution has issued a certificate, receipt cheque, money order, draft or other instrument in respect of which it is primarily liable. Depositors need to know that the law limits the amount of insurance the DIS can pay to depositors when an insured bank fails. As a precaution, depositors of member institutions (insured financial institutions) are required to know whether deposit product is covered under the DIS (Nnamani et al., 2017).

\section{(i) Total Amount Insured:}

It measures total of legally specified amount in a contract a compulsory payment by insurer as liability for the insured or beneficiary. Ahmed (2012) used this variable to measure the financial performance of Jordanian Arab bank. Insured amount specifies the financial value which shall be due and owing on the applicable payment date.

\section{(ii) Total Bank Insured Premium:}

This is the amount of money paid by insured banks to NDIC for the protection of depositors' funds. This amount is expressed in naira. It could be seen as the amount of money a banks pays for an insurance policy. It is an income for an insurance company. It provides financial support to enable indemnification of depositors in the event of bank failure default (Emenuga, 2019).

\section{(iii) Liquidation Dividends:}

In banking, this is the depositor's compensations or payment in the event of failure of a bank. It is usually realized from the sale of the bank's assets and recovered debts (Egboro, 2016). It is funds paid to shareholders during a partial or full liquidation in percentages. Corporation's debt must be paid before it can pay liquidation dividends based on the amount and number of shares held. Adegbaju and Olokoyo (2008) used it to measure recapitalization and performance selected banks in Nigeria. Increase in liquidation dividend portrays better performance.

Dependent Variable: The study anchors on the outcome of the level of return on assets as measurement of banks performance. Return on assets is explained thus;

\section{(i) Return on Assets}

This is a measure of the effectiveness/efficiency of an organization/firm in the utilization of her assets to generate revenues usually calculated as net income divided by total assets. It is the single most important ratio used in comparing performance of a banks or firm. Profitability and performance is indicated through return on assets of an organization (Adegbie et al., 2019).

\section{Analytical Techniques}

The model parameters were estimated using the Ordinary Least Square regression (OLS) method. Results were descriptively discussed and generated graphs discussed to establish the trend of banks performance within the period reviewed using dependent and independent variables; return on assets (ROA, number of depositors insured, total bank insured premium, total bank deposits and liquidation dividend. 


\section{DATA PRESENTATION AND TREND ANALYSIS}

\section{Presentation of Data}

Table 1. Data used for the Analysis

\begin{tabular}{|c|c|c|c|c|c|}
\hline Year & $\begin{array}{l}\text { Returns on Assets } \\
\text { (ROA) } \%\end{array}$ & $\begin{array}{l}\text { Number of } \\
\text { Depositors Insured } \\
\text { (NDI) (million) }\end{array}$ & $\begin{array}{l}\text { Liquidation } \\
\text { Dividend (LD) } \\
\text { ( billion) }\end{array}$ & $\begin{array}{l}\text { Total Bank } \\
\text { Deposits } \\
\text { (TBD) } \\
\text { ( billion) } \\
\end{array}$ & $\begin{array}{c}\text { Total Bank } \\
\text { Insured Premium } \\
\text { (TBIP) } \\
\text { ( billion) }\end{array}$ \\
\hline 1990 & -0.005 & $1,040,573.00$ & $700,103.00$ & 800.62 & $60,664.00$ \\
\hline 1991 & 0.004 & $1,250,860.00$ & $750,430.00$ & 812.46 & $65,128.00$ \\
\hline 1992 & 0.005 & $2,400,805.00$ & $780,286.00$ & 815.37 & $70,456.00$ \\
\hline 1993 & 0.011 & $3,000,032.00$ & $800,795.00$ & 830.49 & $73,880.00$ \\
\hline 1994 & 0.013 & $3,000,548.00$ & $870,880.00$ & 870.58 & $80,714.00$ \\
\hline 1995 & 0.026 & $5,012,820.00$ & $900,450.00$ & 900.05 & $83,820.00$ \\
\hline 1996 & 0.035 & $5,241,896.00$ & $1,100,350.00$ & 950.06 & $88,661.00$ \\
\hline 1997 & 0.019 & $6,338,008.00$ & $1,250,000.00$ & 980.45 & $90,220.00$ \\
\hline 1998 & 0.021 & $7,389,306.00$ & $1,340,645.00$ & $1,000.72$ & $92,300.00$ \\
\hline 1999 & 0.024 & $8,463,284.00$ & $2,000,680.00$ & $1,005.80$ & $100,500.00$ \\
\hline 2000 & 0.024 & $8,579,320.00$ & $2,003,863.00$ & $1,008.12$ & $100,687.00$ \\
\hline 2001 & 0.016 & $10,222,008.00$ & $2,108,425.00$ & $1,017.20$ & $120,432.00$ \\
\hline 2002 & 0.026 & $12,108,621.00$ & $3,284,910.00$ & $1,226.60$ & $125,685.00$ \\
\hline 2003 & 0.020 & $15,894,211.00$ & $3,294,842.00$ & $1,415.80$ & $129,441.00$ \\
\hline 2004 & 0.031 & $18,633,110.00$ & $3,352,681.00$ & $1,814.75$ & $132,328.00$ \\
\hline 2005 & 0.029 & $20,343,883.00$ & $4,338,598.00$ & $2,469.07$ & $135,110.00$ \\
\hline 2006 & 0.027 & $22,158,662.00$ & $4,157,090.00$ & $3,412.30$ & $140,486.00$ \\
\hline 2007 & 0.059 & $28,426,319.00$ & $5,980,967.00$ & $5,351.20$ & $153,320.00$ \\
\hline 2008 & 0.039 & $30,331,614.00$ & $7,147,383.00$ & $8,702.00$ & $168,300.00$ \\
\hline 2009 & -0.093 & $40,126,999.00$ & $7,147,239.00$ & $9,989.80$ & $224,392.00$ \\
\hline 2010 & -0.039 & $44,439,348.00$ & $7,597,411.00$ & $10,837.14$ & $295,720.00$ \\
\hline 2011 & 0.021 & $45,904,247.00$ & $6,681,540.00$ & $12,330.54$ & $356,880.00$ \\
\hline 2012 & 0.026 & $53,629,029.00$ & $6,821,640.00$ & $14,386.33$ & $425,210.00$ \\
\hline 2013 & 0.023 & $62,433,690.00$ & $6,824,194.00$ & $16,677.16$ & $508,060.00$ \\
\hline 2014 & 0.023 & $64,314,151.00$ & $6,831,518.00$ & $18,034.84$ & $614,160.00$ \\
\hline 2015 & 0.023 & $67,014,595.00$ & $426,324.00$ & $17,511.64$ & $725,580.00$ \\
\hline 2016 & 0.015 & $83,016,654.00$ & $6,796,608.00$ & $18,591.23$ & $827,890.00$ \\
\hline 2017 & 0.005 & $99,114,035.00$ & $8,237,573.00$ & $19,380.21$ & $959,560.00$ \\
\hline 2018 & 0.016 & $78,364,858.00$ & $5,573,005.00$ & $18,379.48$ & $781,797.00$ \\
\hline
\end{tabular}

Source: NDIC Annual Statistical Report (1990 - 2018).

\section{Data Analysis and Findings}

Data were subjected to econometric analysis which provides the basis for the findings. The analysis starts with descriptive statistics and test for stationarity of the variables, carried out using the ADF test. The long run relationship is further determined using the Johansen cointegration test before the model estimation. 
Journal DOI: www.doi.org/10.46654/ij.24889849

Article DOI: www.doi.org/10.46654/ij.24889849.s6552

Descriptive Statistics

Table 2. Descriptive Statistics

\begin{tabular}{lccccc}
\hline & ROA & NDI & LD & TBD & TBIP \\
\hline Mean & 0.015586 & 29248051 & 3762084. & 6603.518 & 266599.3 \\
Median & 0.023000 & 18633110 & 3294842. & 1814.750 & 132328.0 \\
Maximum & 0.059000 & 99114035 & 8237573. & 19380.21 & 959560.0 \\
Minimum & -0.093000 & 1040573. & 426324.0 & 800.6200 & 60664.00 \\
Std. Dev. & 0.026600 & 28626181 & 2704647. & 7120.865 & 266924.8 \\
Skewness & -2.583453 & 0.910444 & 0.224177 & 0.736784 & 1.369247 \\
Kurtosis & 11.25467 & 2.632954 & 1.434471 & 1.846287 & 3.488364 \\
& & & & & \\
Jarque-Bera & 114.5940 & 4.169177 & 3.204383 & 4.232136 & 9.349897 \\
Probability & 0.000000 & 0.124358 & 0.201455 & 0.120505 & 0.009326 \\
& & & & & \\
Sum & 0.452000 & $8.48 \mathrm{E}+08$ & $1.09 \mathrm{E}+08$ & 191502.0 & 7731381. \\
Sum Sq. Dev. & 0.019811 & $2.29 \mathrm{E}+16$ & $2.05 \mathrm{E}+14$ & $1.42 \mathrm{E}+09$ & $1.99 \mathrm{E}+12$ \\
& & & & & \\
Observations & 29 & 29 & 29 & 29 & 29 \\
\hline
\end{tabular}

Source: Eviews Output

The table above shows results of the statistical variables used in the model. It can be observed that Returns on assets has mean value of 0.0156 indicating that on the average, ROA has been positive for the period reviewed. The median showed a value of 0.0230000 reflecting from 2013 to 2015. The maximum value of 0.059000 was observed in 2007 which was the pick of ROA for banks within the period reviewed while a minimum value of 0.093000 reflected in 2009 as the lowest within the same period with a standard deviation of 0.026600 . Also, with a Jarque Bera Statistics of 114.59 (p-value $=0.0000$ ), we can conclude that the data on ROA is not normally distributed. This implies that the data on Returns on Assets is negatively skewed from the mean with skewness estimated at -2.583 .

For the number of depositors insured (NDI), a median of 186,331,106 was observed within the period. A maximum number of insured customers rose to 99,114,035 in 2017 which reflected a pick in customers that opened account with banks. It could be deduced that more products were introduced to capture existing opportunities at the same time adopting more marketing and NDIC strategies. A minimum of 1,040,573 customers were revealed in the 1990 which was a base year for the period reviewed in this study. An increase in NDI after that year also attest to better innovations which may have resulted to diversification and NDIC supervision strategies. A jarque-Bera statistics of 4.169 (p-value $=0.1244$.) implies that the data on ROA is normally distributed thereby implying that the data do not deviate far from the mean.

For liquidation dividend (LD), a median value of N3, 294,842.00b was attained in 2003. It showed a relatively low amount paid compared to succeeding years as liquidation dividends are usually paid after assets of failed banks have been sold. It explains that actually, banks and other financial institutions under the control of NDIC failed which may have warranted payments of such value as liquidation dividend. A maximum value of N8, 237,573b was paid in 2017 which depicted the pick of financial sector challenges as the figure showed more payment of liquidation dividends to customers of failed banks. Also, a minimum value of 
N426, 324.00 was paid as liquidation dividend in 2005 which revealed a drop in failed banks. On the average, NDIC paid liquidation dividend of 3,762,084b for the period under review. Though the distress may be there, but may have been rescued through NDIC controlling activities. There is a jarque-Bera statistics of 3.204383 ( $\mathrm{p}$-value $=0.1201)$ implying that the data do not disperse too far away from the mean i.e. it is normally distributed.

Banks attained a value of N1.814 trillion as total bank deposits in 2004 as median for total bank insured deposits (TBD). As shown in table 2. A maximum value of N19, 380.21 trillion was indicated in 2017. The increase in deposit explained that there were higher deposit values from customers to banks. A value of N800, 620 trillion was reflected as minimum in 1990 which was the base year for the period studied. It further showed that there were innovations in the succeeding years which triggered a rise in bank deposits. The variable in the model has a Jargue-Bera statistics of 4.232 with a p-value of 0.1206 ; thus the data is normally distributed.

For total bank insured premium (TBIP), a median value of N132.328b was observed in 2004. The maximum showed a value of N959.569b attained in 2017 for the period reviewed while a minimum value of N60.664b reflected in 1990. Though a base year for the study, there were increases in total bank insured premiums which explains the effectiveness of the NDIC in ensuring safe-keeping of customers' funds for the period reviewed. Also, the data on total bank insured premium has a Jarque-Bera statistic value of 9.350 with p-value of 0.0093; thus we can conclude that it is not normally distributed with a high positive skewness of 1.369 and kurtosis estimated at 3.488. Furthermore, number of deposits insured (NDI), liquidation dividend (LD), total bank deposits (TBD) and total bank insured deposits (TBID) have mean values of 29.24 million, 3.76 billion, 6,603 trillion and 266.60 billion for the years reviewed.

Graphically, the descriptive statistics also show that NDI, LD and TBD are normally distributed while TBIP is not normally distributed. The minimum and maximum figures for each of the variables are summarized as well.

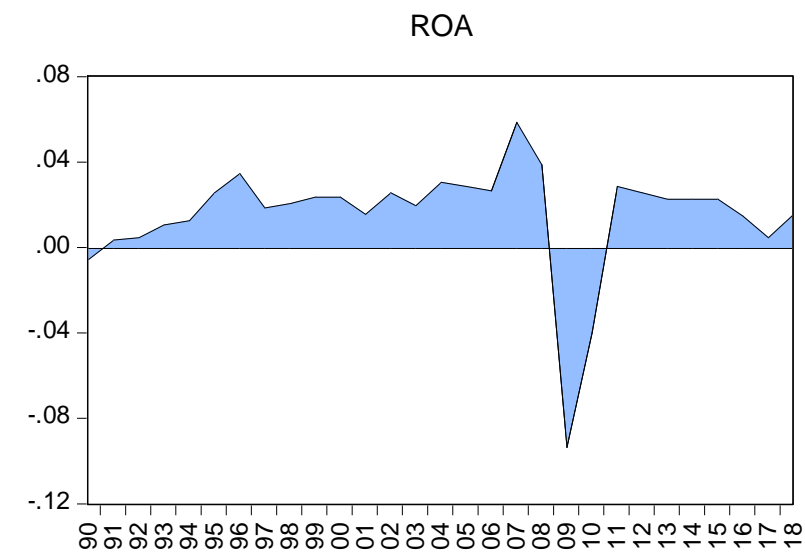

Fig 1: Returns on Assets (1990 - 2018)

Returns on Assets averaged 0.03 within the period 1990 to 2007. Interestingly, the ROA recorded in 2007 represents an all-time high point in the banking sector. However, in 2009, due to the effects of the bank consolidation exercise, ROA of banks starts to decline but picks up again in 2011 and has averaged 0.019 since 2012 up to 2018. 
NDI

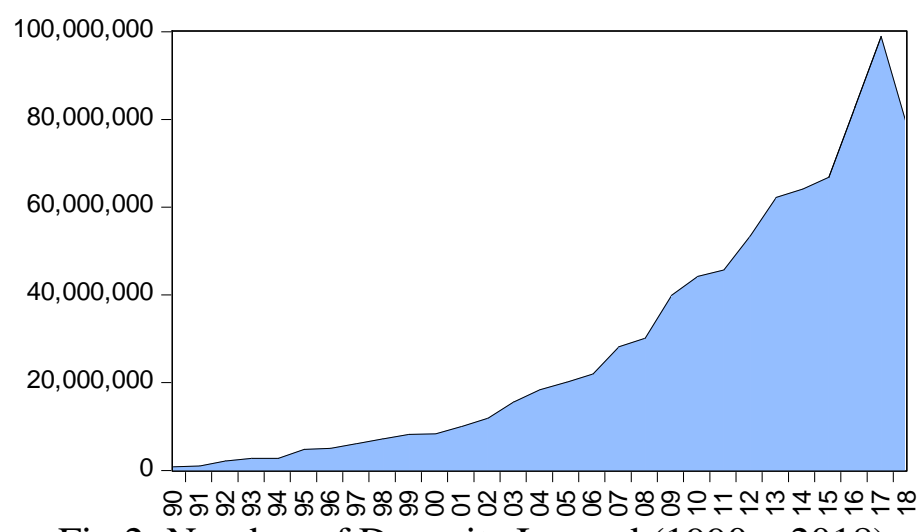

Fig 2: Number of Deposits Insured $(1990-2018)$

The number of insured deposits has been on a steady rise since 1990. It rose to an all-time figure of N99.114 million but fell sharply for the first time in 29 years to a figure of about N78.364 in 2018.

LD

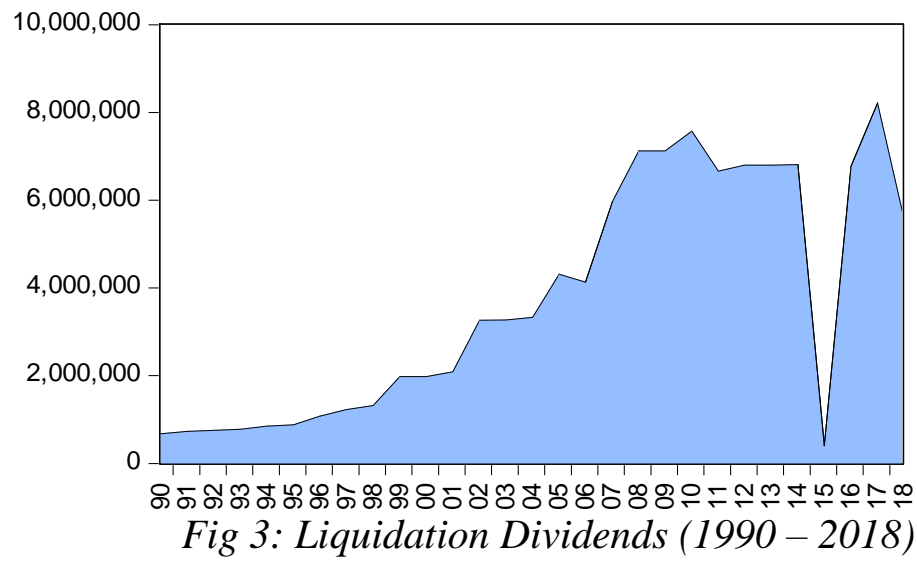

Liquidation dividend increased from N700 thousand in 1990 to 2.003 billion in 2000 . However, the high point of 6.832 billion in 2014 was met with a very sharp fall to about N426 million but rose again and reached N5.573 billion as at 2018 .

TBD

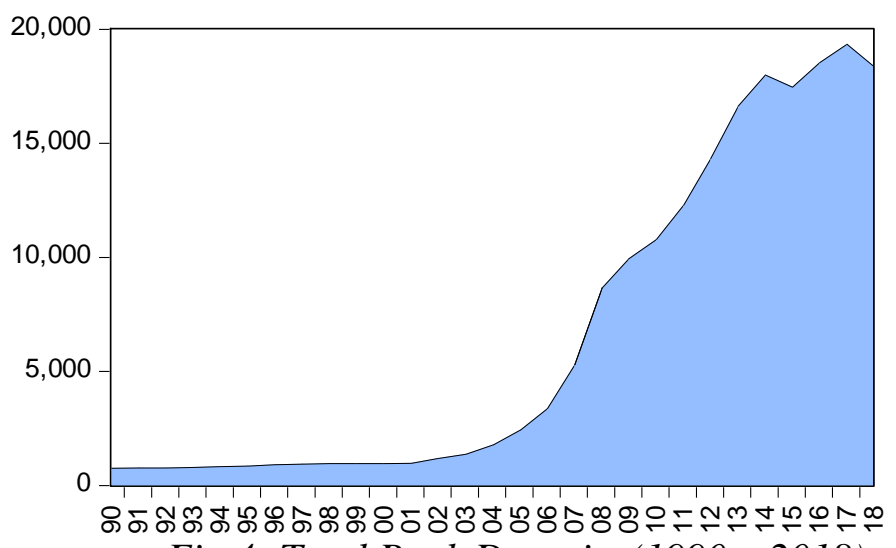

Fig 4: Total Bank Deposits (1990 - 2018) 
The total amount deposited averaged N900 billion from 1990 to 2000. The steady rise was capped with a high point in 2017 when it reached N19.380 billion but fell slightly to N18.379 in 2018. This explains that there were increases in total bank insured premiums which explains presence of more customers and deposits.

TBIP

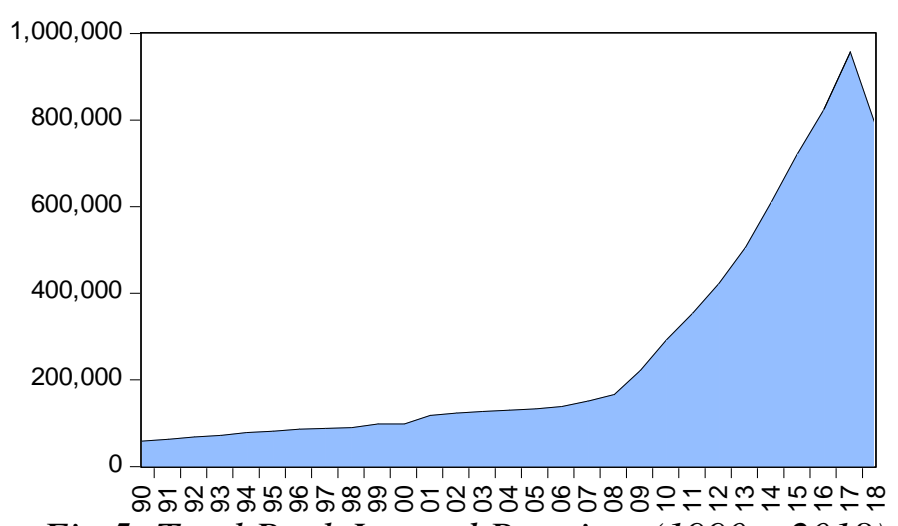

Fig 5: Total Bank Insured Premium (1990 - 2018)

Total bank insured premium by the NDIC averaged N98.88 billion from 1990 to 2005. This continued to rise and peaked at N959.56 trillion in 2017 before falling slightly to N781.80 trillion in 2018.

\section{Discussion of Findings}

From the trend, it is evident that the number of depositors insured has a positive and significant effect on the returns on assets of the selected banks while liquidity dividend decreases the returns on assets and does not affect significantly affect the banks' performance in the short run. The total banks deposits decrease the banks' returns on assets but not significantly and the insured bank premium increases the performance of selected banks. This is consistent to the findings of Udo, (2015) that rescued Nigerian banks are still not sound and stable in their operations, indicating that NDIC's supervisory efforts do not have any significant impact on the rescued banks provisions and arrangements for risks and obligation of paying depositors of affected banks does not have any significant impact on the stability of the Nigerian banking system. It also agrees with the work Demirguc-Kunt, Kane \& Laeven (2008), cited in Nwakoby et al. (2016) who argued that in any deposit insurance scheme, the amount of coverage matters. This coverage is determined by total bank's deposit, which ultimately affects market discipline by ensuring that depositors are protected.

Again, the number of insured deposits has been on a steady rise since 1990. Total depositors insured has a significant relationship with banks' returns on ROA. A unit change in the insured deposits will result to units increase in the banks' returns on assets. There is inverse and negative relationship between liquidation dividends paid to the banks' shareholders by the NDIC and the banks' returns ROA. Though the relationship is inverse, Osadume \& Ibenta (2018) in their findings, showed consistency in terms of banks performance with significant relations in adequacy of liquidity and quality of assets. The total amount deposited averaged N900 billion from 1990 to 2000. The steady rise was capped with a high point in 2017 but fell slightly in 2018. 
There is also a positive and significant relationship between the premium paid on insured deposits and the banks' ROA and a change in the amount of bank insured premium increases banks' performance. Overall result show that banks' performances decrease steadily without the operations NDIC in Nigeria. This explains that there were increases in total bank insured premiums which explains the presence of more customers and deposits. Total banks deposits with the NDIC has not yielded positive effect on their performance which negates the a-priori due to insufficient deposits with the NDIC.

\section{Conclusion and Recommendations}

The Banking industry reform in Nigeria created more responsibilities for the NDIC to oversee the activities of banks using majorly the extant laws found in corporate governance, deposit insurance scheme (DIS) and its supervisory framework. The adoption of descriptive approach in this study helped for better understanding of in-depth explanations on the activities and performances of banks in Nigeria. The findings revealed increase in banks return on assets of banks have appreciated since after the 2004 banking reforms. The study concluded that there is a dual impact of the banking industry reforms on Nigeria's economic growth and suggested the following. Nigeria Deposit Insurance Corporation should embark on strict supervision, within their authority, to prevail on every bank to transmit their premiums as and when due. In pursuit of corporate governance, NDIC should ensure that every loan taken from the banks are traced to the real borrower to avoid insider loan which has been the cause of major bank failures. 


\section{References}

Abdulazeez, D. A., Ndibe, L \& Mercy, A. M., (2016). "Corporate Governance and Financial Performance of Listed Deposit Money Banks in Nigeria". Journal of Accounting \& Marketing (2016), 5(1), 1 - 6. DOI: 10.4172/2168-9601.1000153

Amire, C. M. \& Amire, P. O. E., (2016). "The Effect of Corporate External Restructuring on the Performance of Financial Institutions in Nigeria: A Review. International Journal of Economics and Financial modeling. 1(1), 1 - 11.

DOI.10.20844/811.1.1.1.11

Antonio, T. P. (2003). "What determines the Profitability of bank? Evidence from Spain. 1 - 35. Available: http://www.aeca1.org/pub/on_line/comunicaciones_xvicongresoaeca/cd/75b.pdf

Ahmed, A. A. (2012). "Financial Performance Analysis of the Jordanian Arab Bank." International Journal of Economics and Finance. 4(4), 86 - 94. doi:10.5539/ijef.v4n4p86

Adegbaju, A. A. \& Olokoyo, F. O. (2008). 'Recapitalization and Banks' Performance: A Case Study of Nigerian Banks. African Economic and Business Review. $6(1), 1-17$.

Adegbie, F. F., Akintoye, I. R. \& Alu, C. N. A, (2019). "Effect of Managerial Efficiency on Corporate Financial Performance of Quoted Nigeria Firms. European Journal of Accounting, Auditing and Finance Research. 7(6). 12-39.

Apere, T. O. (2016). Return on Assets and Capital Adequacy of Banks in Nigeria. Advances in Social Sciences Research Journal. 3(12), 139 - 149. Doi:10.14738/assrj.312.2117

Central Bank of Nigeria annual report Publication (2010): Bulletin, January-march

Davis, J., Schoorman, R. and Donaldson, L. (1997) Towards a Stewardship Theory of Management. The Academy of Management Review, 22, 20 - 47..

Dhar. S. \& Bakshi, A. (2013). "Impact of Corporate Governance on Profitability of Banks: A Study on Listed Indian Banks .Available: file:///C:/Users/John/Downloads/jrfm-12-00138-v2.pdf

Emenuga, P. (2019). "Equity Financing and Bank Performance in Nigeria: Special Performance in First Bank in Nigeria." Journal of Humanities and Social Sciences. 24(4), $17-33$.

Ganiyu, O. (2014). "What's New at IADI?” Africa Regional Meeting and Conference Deposit Insurance in Africa: Issues, Challenges and Prospects. 12 - 23. Accessed from https://www.iadi.org/en/assets/File/Newsletters/Vol2/IADI_NewsLetter_Vol2_Iss12. $\underline{\mathrm{pdf}}$

Gidigbi, M. O. (2017). "An Assessment of the Impact of Banking Reforms on Economic Growth and Bank Performance in Nigeria". CBN Journal of Applied Statistics. 8(2), 23 -50 . 
Available::https://www.cbn.gov.ng/out/2018/sd/an\%20assessment\%20of\%20the\%20i mpact\%20of\%20banking\%20reforms\%20on\%20economic\%20growth\%20and\%20ba nk\%20performance\%20in\%20nigeria.pdf

Gujarati, D. N \& Peter, D. C. (2009). “Basic Econometrics $5^{\text {th }}$ Edition, Singapore, McGraw-Hill International Edition.

Ibrahim J, Adesina K.O, Olufowobi T.A. \& Ayinde P.K. (2018). Corporate Governance and Return on Assets of Quoted Banks in Nigeria. International Journal of Business and Management Review. 6(10), 1- 13.

Iwedi, M. (2018). "Bank Failure in Nigeria: Evidence of Prudential Regulator Laxity". International Journal of Finance and Management. 5(2), 141 - 150.

Iyede, O. Onah, F. E. \& Osusu, O. O. (2018). "The Concept of Banking Crisis and its Periods of Occurrence in Nigeria". European Journal of Business and Management 10(3), 86 99.

Jorge, P. M. \& Serna-Gómez, H. M. (2012). Corporate Governance Structure and Its Impact on Human Resource Management and Financial Performance. China-USA Business Review, 11(8). 1133-1145.

Mohammed, H. (2018). "Evidence Determination of Bank Failure Eradication in the $21^{\text {st }}$ Century Nigeria". Journal of Business and Financial Affairs. 7(2), 1 - 5. DOI: $10.4172 / 2167-0234.1000341$.

Nzotta, S. M. (2004). Money, Banking and Finance: Theory and Practice. $2^{\text {nd }}$ Edition. HudsonJude Nigeria Publishers.

Nnanna, O. J. (2003). Today's banking risks and current regulatory and supervisory framework Bullion 27 (3), July/September.

Nwakoby, I., Onwumere, J., Ibe, I. \& Okanya, O., (2016). “The Impact of Deposit Insurance Scheme on Bank Intermediation in Nigeria". European Journal of Social Sciences. 53(1), $64-79$. Accessed on $16^{\text {th }}$ October, 2019 fromhttp://europeanjournalofsocialsciences.com/

Ogunleye, G. A., (2003). Official Safety-nets for the Nigerian Financial System: The Role of the Nigeria Deposit Insurance System. CBN Seminar on Issues in Financial Institutions Surveillance in Nigeria. Publication of CBN Training Centre, Lagos.3, 80-98. https://www.cbn.gov.ng/out/publications/guidelines/pid/2004/surveillance.pdf

Ogboru, M. J. (2019). Asset Quality and Deposit Money Banks Performance in Nigeria. American International Journal of Business and Management Studies, 1(1). 38 - 47.

Oje, A. T. \& Oladele, S. A. (2017). Empirical Investigation of the Financial Performance of Deposit Money Banks before and After Banking Sector Reforms in Nigeria. Research Journal of Finance and Accounting. 8(7), 44 - 52.

Osadume, R \& Ibenta, S (2018). "Evaluation of the Financial Performance of Deposit Money Banks in Nigeria (2001 - 2014)" International Journal of Banking and Finance Research. 4(2), $45-58$. 
Oriaregbete, S. (2016). "Assessing CBN Regulation and Banking Operations in Nigeria: A Theoretical Discuss. Journal of Economics and management. 4(2), 1 - 16.

Schoorman, F. D., Wilson, K. W., Davis, J. H., Hundley, G. S., \& Bagnoli, M. E. (2012). Governance Philosophy at the Relational Level: Putting Stewardship into Action 9. West Lafayette, IN: Purdue University. Available at; file:///C:/Users/USER/AppData/Local/Temp/43779051.pdf

Udo, S. I., (2015). "The Effectiveness of Nigerian Deposit Insurance Company Operations (NDIC) in Stabilizing the Nigerian Banking Sector.

Available:https://www.google.com/search?sxsrf=ACYBGNRwji86CPPA5rlRFJiQBn 9rjIqk9w: $1573122626539 \& \mathrm{q}=$ performance + of + NDIC+in+banks+supervision+in+nig eria\&spell=1\&sa=X\&ved=0ahUKEwjg8d668tflAhUSWsAKHWyZBvgQBQgsKAA $\underline{\text { biw }=1093 \& \text { bih }=461}$ 